Article

\title{
Does CSR Influence Firm Performance Indicators? Evidence from Chinese Pharmaceutical Enterprises
}

\author{
Minghui Yang ${ }^{1} \mathbb{D}$, Paulo Bento ${ }^{2}$ and Ahsan Akbar ${ }^{1, *}$ \\ 1 International Business School, Guangzhou College of South China University of Technology, \\ Guangzhou 510800, China; yangmh@gcu.edu.cn \\ 2 ISCTE Business School, University Institute of Lisbon, 1649-026 Lisbon, Portugal; paulo.bento@iscte.pt \\ * Correspondence: akbar@gcu.edu.cn
}

Received: 9 August 2019; Accepted: 8 October 2019; Published: 14 October 2019

\begin{abstract}
This research is carried out in the backdrop of increasing product quality and environmental degradation scandals associated with Chinese Pharmaceuticals in recent years. We examined the data of 125 Chinese Pharmaceuticals between 2010-2016 to investigate the impact of overall corporate social responsibility (CSR) performance as well as the performance on five unique aspects of CSR such as shareholders, employees, customers and suppliers, environmental practices, and the society to gauge the impact of these individual dimensions on the firm's financial performance. The Hexun rating system is used to gauge a firm's CSR performance on various stakeholder dimensions as it is one of the widely accepted CSR measurement criteria in China. The firm performance is measured by Tobin's $Q$, return on assets (ROA), return on equity (ROE), and earnings per share (EPS) ratios. The outcome of the panel-based regression models reveals that the overall CSR score has a positive and significant influence on a firm's financial indicators. Moreover, although all the CSR dimensions relate positively to firm performance, the environmental aspect of CSR has the most profound impact on firm performance followed by customers and suppliers, and employees. However, the shareholders and social dimensions have a relatively lesser influence on firm performance. These results imply that Chinese Pharmaceuticals shall further optimize each aspect of CSR performance as it can not only create a favorable brand image for various stakeholders but also results in sustainable financial performance.
\end{abstract}

Keywords: CSR dimensions; chinese pharmaceuticals; mixed-method approach; firm performance

\section{Introduction}

Corporate social responsibility (CSR) has gained momentum as a critical issue for many firms because of the increase in public awareness about the impact of corporate activities on the environment and society [1]. Companies are expected to act in a socially responsible manner as well as be financially accountable [2]. Recently, CSR evokes public attention in China because of the increasing number of incidents concerning product safety and environmental pollution. The widespread perception of lacking social responsibility in Chinese firms has become a primary driver for CSR expansion in China [3].

The improvement in firm performance is a critical factor for firms to decide whether or not to implement particular organizational policies and practices [4]. Prior literature has not yet reached a consensus on the nature of the relationship between CSR and firm performance $[5,6]$. Disagreements on the adoption of CSR still persist, reflecting the higher costs of CSR practices which may contradict the primary goal of profit maximization $[7,8]$. Notwithstanding, recent empirical studies suggest that CSR is beneficial for firm performance by enhancing employee satisfaction, attracting ethical customers, 
and building a better corporate image $[9,10]$. However, this positive association might not prevail during the course of a financial crisis as witnessed during the U.S. financial turmoil of 2008 [11].

The dilemma of CSR promotion is more evident in corporate China, where economic motives are highly emphasized in CSR-related decision making [12]. Based on the analysis of 1533 media reports concerning food safety scandals, Zhang and Xue [13] exposit that economically motivated frauds were a serious and emerging food safety issue in China. Given the increasing demand for high-quality drugs and reliable medical services, pharmaceutical firms are financially challenged in the global markets [14]. Undoubtedly, medication is directly associated with people's well-being. The popularity of environmentalism, the increased buying power, and the globalization of medical business also led to the spread of CSR practices in the context of the pharmaceutical industry $[15,16]$. Unlike other industries, there is a difference of opinion about the positive effects of CSR related investment on the performance of Chinese pharmaceuticals. Pharmaceutical firms usually feel reluctant to implement costly CSR practices partly due to excessive resources assigned to R\&D and the promotional activities required in this type of business [17].

\section{Product-Related Incidents in Chinese Pharmaceuticals}

Wang and $\mathrm{Xu}$ [17] contend that the CSR performance of Chinese Pharmaceuticals receives special attention from various stakeholders for the following reasons:

The first rationale is about responsibility for product quality. The quality of drug-related products and services corresponds to human health, which is critical in the public eye. This responsibility includes the reliability of drug information disclosure and the safety of product treatments. Pharmaceutical companies should take care of low-income groups by providing high-quality products at affordable prices.

The second reason is concerned with responsibility toward the supply chain. Pharmaceutical companies should ensure the safety and quality of raw materials deployed in the manufacturing process. Additionally, the safety and reliability of the R\&D process should also be taken into consideration. Thirdly, Advertising for drug-related products and services should be reliable and not unrealistic. Pharmaceutical companies should also supervise and control products' promotional activities. Fourthly, Pharmaceutical companies are obligated to educate local communities for disease prevention and the safe use of drugs. In addition, pharmaceutical firms need to intensify collaboration with local groups and associations in terms of health training.

Fifthly, such firms shall take full responsibility toward recycling of expired drugs. Expired drugs have considerable side-effects that may be harmful to human health and the surrounding environment. It is essential for pharmaceutical companies to establish an effective supervisory system to control recalls for medications as well as disposal of outdated drugs. Lastly, the pharmaceutical company should deliver clinical and trial tests in safe ways and supervise medical tests before the new launch of drug-related products and services.

In the last decade, there have been several critical incidents involving drug-related products or services in China. Table 1 illustrates the incidents of China's pharmaceutical companies between 2006 and 2017 [18].

This paper delves into the CSR performance data of Chinese pharmaceutical companies from the Hexun CSR database, which consists of 38 measures over five dimensions of CSR practices between 2010 and 2016. The weight of each CSR dimension namely shareholders, employees, customers and suppliers, environmental practices, and society is taken from the Hexun CSR rating system as it is the most trusted source of CSR evaluation in China. Subsequently, the panel-based regression models are developed to test the corresponding hypotheses. Each CSR dimension was regressed with the firm performance indicators to adequately address the research questions raised in this study.

The present study examines whether CSR activities are a way for Chinese Pharmaceuticals to improve their financial performance. The study makes the following contributions to the extant literature on CSR. First, unlike previous studies, which take the overall Hexun CSR score to proxy 
the firm's CSR performance, we employ econometric models on each CSR dimension to assess the significance of a particular dimension in impacting the firm's financial fundamentals. Second, owing to the unique business model, pharmaceuticals have a direct influence on environmental quality and public well-being. Nevertheless, such firms have to allocate more resources to R\&D and promotional activities, leaving fewer funds to actively engage in CSR practices. This unique business model makes it very interesting to investigate how pharmaceutical firms manage this trade-off and their perception of CSR. Third, in the backdrop of numerous product quality scandals reported in the Chinese pharmaceutical industry in recent years, it is essential to explore the managerial attitude towards the CSR activities and its perceived impact on firm performance in this particular industry setting.

Table 1. Drug-related product incidents in China, 2006-2019.

\begin{tabular}{|c|c|c|}
\hline Date & Incident & Consequence \\
\hline 2019 & $\begin{array}{l}\text { Explosion in glutamine manufacturing line of } \\
\text { Shenhua Pharma in Jiangsu Province. }\end{array}$ & $\begin{array}{l}\text { Eight persons were severely injured, one } \\
\text { person died. }\end{array}$ \\
\hline 2018 & $\begin{array}{l}\text { Injurious hydrophobia vaccine made by Changsheng } \\
\text { Pharma in the Jilin Province. }\end{array}$ & $\begin{array}{l}\text { All vaccines were not sold yet, } 15 \text { criminals } \\
\text { including senior management were arrested. }\end{array}$ \\
\hline 2017 & $\begin{array}{l}\text { False DPT (Diphtheria, Pertussis, Tetanus) vaccine } \\
\text { made by Changsheng Pharma in the Jilin Province. }\end{array}$ & $\begin{array}{l}252,600 \text { vaccines confiscated in the } \\
\text { Shangdong Province. }\end{array}$ \\
\hline 2017 & Misleading advertising for eye drops by SPAS. & $\begin{array}{l}\text { There was a significant drop in share price by } \\
40 \% \text { within a week. }\end{array}$ \\
\hline 2016 & $\begin{array}{l}\text { Injurious vaccine made by an illegal medical factory } \\
\text { in the Shandong Province }\end{array}$ & $\begin{array}{l}\text { Vaccines spread into over } 10 \text { provinces and } \\
\text { some children were infected. }\end{array}$ \\
\hline 2014 & $\begin{array}{l}\text { Counterfeit drugs to treat diabetes manufactured in } \\
\text { the Henan Province. }\end{array}$ & Several patients were affected. \\
\hline 2013 & $\begin{array}{l}\text { Injurious vaccine from Kangtai Pharma in the } \\
\text { Guangdong Province. }\end{array}$ & $\begin{array}{l}\text { Seven newborn babies died. Deaths were } \\
\text { suspected to be caused by the vaccine. }\end{array}$ \\
\hline 2012 & $\begin{array}{l}\text { Toxic capsules made by Hengtai Pharma in the } \\
\text { Jiangsu Province. }\end{array}$ & $\begin{array}{l}\text { Thirteen batches of capsules had excessive } \\
\text { chromium. }\end{array}$ \\
\hline 2011 & Plasticizer scandal in Taiwan. & $\begin{array}{l}\text { It spread to } 294 \text { companies and a total of } 973 \\
\text { different products. }\end{array}$ \\
\hline 2009 & $\begin{array}{l}\text { Poor quality of Coptis chinensis injection in the } \\
\text { Heilongjiang Province. }\end{array}$ & One death was reported in this incident. \\
\hline 2008 & $\begin{array}{l}\text { Injurious vaccine made by Huawei Pharma in the } \\
\text { Shanxi Province. }\end{array}$ & One death was reported in this incident. \\
\hline 2006 & $\begin{array}{l}\text { Visible particles existed in glucose and sodium } \\
\text { chloride injections in the Hebei Province. }\end{array}$ & $\begin{array}{l}\text { Nine patients were affected and adverse } \\
\text { reactions occurred. }\end{array}$ \\
\hline
\end{tabular}
Source: Website of China Food and Drug Administration (2019).

The rest of the paper is organized as follows. Section 2 elaborates the literature review and develops corresponding hypotheses. Section 3 describes the data and methodology. Section 4 reports results of analysis and unfolds discussions. Section 5 concludes the study.

\section{Literature Review and Hypotheses Development}

\subsection{Evolution of CSR}

CSR was initially proposed by Shelton in 1924 . He argued that preserving the interests of society is the main responsibility of an enterprise while it pursues the profit motive [19]. The uprising phase of CSR began in 1950 when Bowen defined CSR as an obligation that businessmen need to follow under the values of a society. The idea of CSR further evolved in 1960 as there was a movement towards environmental protection, customers' rights, and women rights. Frederick [20] suggested 
that firms need to enhance socioeconomic welfare and fulfill the expectations of the general public. David [21] extended CSR to the moral standpoint and stated that CSR is the right thing for firms to do. In 1970 the scope of CSR was further elaborated by scholars and organizations. For instance, Johnson [22] proposed that the dimensions of CSR encompass employees, suppliers, dealers, local community, and the government. The Committee for Economic Development (CED) also elucidated the CSR concept through three concentric circles. The inner circle depicts the core functions such as economic growth and job satisfaction. The intermediate circle concerns the responsiveness such as environmental protection and information disclosure of CSR activities. The outer circle relates to the well-being of society and ecosystem such as eradicating poverty and urban blight issues [23]. Undoubtedly, the most well-known definition was proposed by Carroll [24], who regarded CSR as the sum of obligation that society expects firms to fulfill. He outlined the three-dimensional conceptual model of corporate social performance. Later, the CSR concept was extended to a four-dimensional model comprising of the economic, legal, ethical, and discretionary dimensions.

The well-known stakeholder theory proposed by Freeman [25] was propagated in 1984. Stakeholder theory suggests that managers need to focus on the groups who influence and are influenced by an enterprise's business activities. Managing relationships with stakeholders, such as stockholders, employees, customers, and community, etc., is imperative for a firm to reach success. CSR relates to the way a company treats stakeholders in terms of moral obligation. Carroll [24] stated that stakeholder theory can explain the motivation of CSR practices, and this is a promising theory to "match" the CSR concept. Not surprisingly, stakeholder theory has been one of the most commonly used notions in CSR literature. In 1990, the focus of CSR shifted to more pragmatic issues [26]. Specifically, scholars tried to link CSR benefits to practical business cases and attempted to address the tangible gains an enterprise may collect from CSR engagement [27]. During the late 1990s, researchers were inclined to incorporate CSR into strategic management so as to establish a connection between the concept and the market outcome [28]. Scholars attempted to associate the CSR strategy with the business strategy level and figure out how a firm could achieve both financial and social benefits for its stakeholders to ensure competitiveness [29]. Since the 20th century, the development of value creation took place in the CSR field. In particular, CSR practices enable companies to add value, such as attracting valuable human resources, cultivating firm image, and so on [30]. Another movement of CSR in the new millennium was the concern for sustainability. CSR was treated as an enterprise's commitment to maximize long-term positive effects and minimize negative impacts on society [31]. Consequently, CSR practices can be embraced as a key component in organizational objectives in order to achieve sustainability [32]. The evolution of CSR is presented in Figure 1.

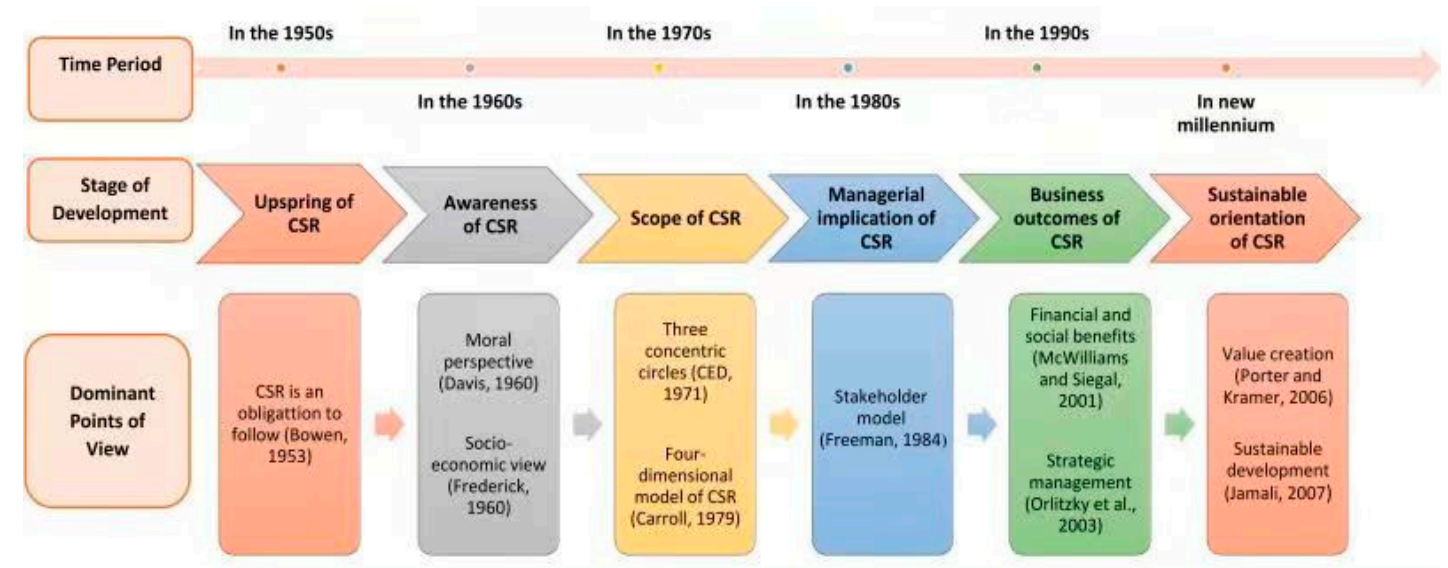

Figure 1. Summary of corporate social responsibility (CSR) evolution, Source: Author (2019). 


\subsection{CSR in China}

The extant literature primarily focused on CSR practices implemented by companies in advanced economies, such as the U.S. and Europe [33,34]. However, few studies have focused on how CSR is perceived and practiced in the emerging economies [4,35]. Admittedly, different institutional environments in terms of a variety of social norms, culture, and traditions may impact CSR practices through the underlying social expectation and public opinion pressures [36]. In addition, countries at different phases of economic development have varied concerns and priorities, indicating that developed countries have an entirely different understanding of CSR application in corporations than their developing country counterparts [16,34]. In the context of emerging economies, there is a need for appropriate frameworks to evaluate CSR performance accurately. Companies in developing economies are less likely to conform to internationally recognized CSR principles and standards. Besides, such firms would regard financial responsibility as a primary obligation, followed by philanthropic, legal, and other discretionary obligations, respectively [37].

Due to the emergence of several scandals about Chinese companies regarding environmental and product safety accidents, CSR has become the focal point of attention for academia, government, and Chinese enterprises. Given the rapid expansion in both the economy and social awareness, the Chinese government plays a vital role in examining and regulating CSR practices, aiming to balance economic growth with social development. The first policy initiative concerning CSR practices is the Company Law which was rolled out in 1994. It explicitly concerns the protection of employee's rights in enterprises [38]. The 2006 Company Law supplements the definition of CSR in Article 5 by stating that CSR is an obligation that the companies are obligated to comply with in order to promote social morality and business ethics under governmental supervision [39]. Given the widespread participation of state-owned enterprises (SOEs) in the Chinese economy, in 2008 the State-owned Assets Supervision and Administration Commission of the State Council (SASAC) released the Guidelines for SOEs in terms of CSR interpretation and implementation [40]. In 2016 the SASAC further promulgated the "Guide on the SOEs' improved CSR performance" to explicitly elaborate the importance and the role of CSR [41].

Regarding the CSR regulation in Chinese stock markets, the Shenzhen Stock Exchange (SZSE) was the first to launch the "Guide on Listed Companies' Social Responsibility" in 2006, promoting voluntary disclosure of CSR reports and advising periodic analysis of CSR performance. In 2008, the Shanghai Stock Exchange (SHSE) released the "Guide on Listed Companies' Environmental Information Disclosure", requiring the following three types of listed companies that need to disclose CSR reports annually if they are in the Corporate Governance Index, simultaneously listed in the domestic and foreign stock markets, or are operating in the financial sector. Based on this criterion, 797 companies listed in SHSE published CSR reports in 2018, and about 278 of them were voluntary disclosures [42]. The number of CSR and voluntary reports is much higher than 2008, which merely contained 290 reports and 32 voluntary disclosures.

\subsection{Stakeholder Theory in Explaining CSR Dimensions}

The pressure exerted by different stakeholders' influences corporate decisions about whether or not to implement CSR practices [9]. Actively responding to stakeholders' concerns is essential for an enterprise to gain a competitive advantage $[43,44]$. Specifically, the stakeholder theory suggests that companies can cause externalities to various parties that have vested interests or "stakes" in the organization. These parties can be internal or external to corporate operations including employees, customers, suppliers, government, and community [25]. As a result of externalities connected with stakeholders, companies are pressured to mitigate adverse effects on society, such as preventing environmental pollution and improving positive image through socially responsible activities, such as charitable donations and community involvement. Therefore, stakeholder theory can explain the motivation of CSR and mainly how a company assigns its organizational resources to manage the relationship with stakeholders, aiming to improve their welfare [6]. 
According to the classification put forward by Donaldson and Preston [45], stakeholder theory can be interpreted as having three aspects that are descriptive, instrumental, and normative. These distinct perspectives of stakeholder theory offer a lens to observe the adoption of CSR and organizational changes based on stakeholder management. For example, the descriptive approach depicts the ways the companies are practicing CSR in terms of stakeholders' interests. The normative approach describes the reason for CSR adoption, specifically focusing on the moral and philosophical aspects. The instrumental approach explains the performance achievement by managing the relationship with stakeholders. In particular, the instrumental aspect of the stakeholder model explores whether a company can benefit from CSR practices with a combination of stakeholders' needs and social trustworthiness that can acquire competitive advantages by maximizing firm value [46]. In a nutshell, it provides a clue to investigate the connection between CSR practices and the fulfillment of corporate objectives such as profitability and sustainable growth.

Many prior studies empirically examined the association between CSR and firm performance in the light of stakeholder theory. Maignan et al. [43] revealed that CSR practices measured by a 5-point scale scoring by external experts have a positive association with financial performance measured by return on assets (ROA), return on investment (ROI), profit growth, and sales growth. Likewise, an empirical investigation of 61 funds from socially responsible investments (SRI) from 1972-2000 shows that CSR practices can improve the average monthly return of SRI funds [47]. Recently, a study investigated the effect of firm visibility on the association between CSR and corporate financial performance in Taiwan, and suggested that firms with better CSR performance can obtain financial results superior to those of firm which would not pursue CSR initiatives. [48]. In the context of the U.S, the largest firms ranked by Newsweek in 2009 demonstrate that CSR can promote financial performance measured by cumulative abnormal returns [9]. From the Chinese perspective, Chen and Wang [36] defined nine types of stakeholders for Chinese enterprises and empirically found that CSR activity can improve financial performance in the current and following year. Subsequently, the data of Chinese national state-owned enterprises (CNSOEs) was examined by Zhu et al. [4]. Their results suggest that CSR practices related to aspects of labor practices, community involvement, supply chain, and political responsibility are positively associated with annual operating performance. Freeman [25] delineates that customers, employees, and suppliers directly influence enterprises, while government, environment, and society indirectly affect companies' performance and operations. The stakeholder theory stresses a necessity for firms to actively engage in CSR practices because they can bring benefits to the companies.

\subsection{Hypotheses Development}

Chinese firms may experience difficulties in achieving sustainable financial performance without effectively promoting CSR practices [49]. Put differently, engaging in CSR activities helps companies to effectively manage the relationship with their stakeholders, who can create, develop, and maintain the link with productive resources [50]. From the perspective of stakeholders, CSR practices enhance their commitment to a firm's operations [51]. The ways Chinese enterprises socially deal with their stakeholders is a key feature to ensure a continued concern [4]. Based on the above discussion; we put forward our first hypothesis to examine whether CSR practices can yield financial returns for Chinese pharmaceutical companies:

Hypothesis 1 (H1). In the Chinese context, pharmaceuticals' overall CSR efficiency can increase firm performance.

The descriptive aspect of stakeholder theory enables us to identify different groups of stakeholders that are connected to firms' CSR efforts. Shareholders are one of the primary stakeholders because of their close association with corporate strategy and operations [52]. Firms would gain financial returns if their financially responsible activities are acknowledged by shareholders and potential investors. Pharmaceuticals are particularly responsible for promoting employees' benefits to periodically perform 
health and safety checks due to the higher risks in the process of new product development, manufacturing, and recycling [16]. The supportive attitude towards employees enables companies to attract, retain, and motivate valuable human resources, resulting in lower turnover rate and higher productivity [53]. Given the increased global production and marketing activities, CSR activities have been extended to supply chain management and product safety maintenance. Especially, drugs are directly associated with human health and well-being, while the high-quality of raw materials and medicines can enhance customer loyalty towards pharmaceuticals along with higher financial gains $[52,54]$. In addition, pharmaceutical companies would regard the environment as an important aspect of their CSR strategy because their negative impacts on the local environment, such as medical disposals and discharges, may be fined by authorities, resulting in substantial short-term costs [55]. Wu et al. [56] argue that environmentally friendly CSR activities promote innovation in Chinese firms through public visibility and firm transparency. Jiang and Akbar [57] reveal that in China's context female executives tend to make a relatively higher amount of environmental protection investments. However, it still remains unclear how green CSR activities advance financial performance of firms. To portray themselves as social citizens, pharmaceuticals are expected to support the local community by promoting health-care education and development, which enable such companies to lobby for tax reductions or preferential policies by the government [52,58]. Thus, based on the above discussion, our second hypothesis examine whether various CSR dimensions of stakeholders enhance financial gains in Chinese Pharmaceuticals.

Hypothesis 2 (H2). In the context of China, pharmaceuticals' favorable CSR practices concerning various stakeholders (shareholders, employees, customers, and suppliers, the environment and society, respectively) can increase firm performance.

\section{Research Design}

\subsection{Sample Selection}

The sample for this study consists of pharmaceutical companies listed on the Shanghai and Shenzhen stock exchange. The data of CSR is collected from the Hexun CSR database, which is one of the biggest third-party rating systems in China that provide specialized information about firms' social performance drawn from 38 indicators under five dimensions. Hexun CSR ratings are widely employed as a valid proxy in measuring CSR performance of Chinese enterprises since 2010 [52,59]. The data of firm performance was obtained from the China Stock Market and Accounting Research (CSMAR) database. Given the integration of Hexun CSR data into CSMAR, we further exclude observations that are labeled as "Special Treatment (ST)" by China's Securities Regulatory Commission as companies experiencing abnormal financial conditions for consecutive years. Our final sample comprises 875 firm-year observations over 7 years between 2010 and 2016. A list of the sample pharmaceutical companies is provided in Appendix A.

\subsection{Variables of the Study}

CSR

CSR is the independent variable of this study. The measurement of CSR is carried out by obtaining data from the Hexun CSR rating [60], which is a top-ranked rating agency that provides professional financial and CSR information of listed companies on the basis of user satisfaction. Hexun was founded in 1996 and launched the CSR evaluation database in 2010. Both the social responsibility reports and the annual reports are assessed by Hexun based on the framework of stakeholder theory. CSR performance is evaluated through five dimensions of stakeholders, comprising shareholders, employees, suppliers and customers, the environment, and society, respectively. These five dimensions include 13 s-class indices and 38 third-class indices [60]. By employing criteria from the Hexun rating 
system, our study assesses overall CSR score and score of each stakeholders' dimension, ranging from 0 to 100 as presented in Table 2.

Table 2. Hexun CSR evaluation framework.

\begin{tabular}{|c|c|c|}
\hline Dimension of CSR Performance & Second-Class Measures & Third-Class Measures \\
\hline Shareholders (weight ratio: 30\%) & $\begin{array}{l}\text { Debt paying (3\%) } \\
\text { Return ( } 8 \%) \\
\text { Credit }(5 \%) \\
\text { Innovation }(4 \%)\end{array}$ & $\begin{array}{c}\text { ROE (2\%) } \\
\text { ROA (2\%) } \\
\text { Return of sales (2\%) } \\
\text { Cost margin }(1 \%) \\
\text { EPS (2\%) } \\
\text { Retained earnings per share (1\%) } \\
\text { Quick ratio }(0.5 \%) \\
\text { Liquidity ratio }(0.5 \%) \\
\text { Cash ratio }(0.5 \%) \\
\text { Equity ratio }(0.5 \%) \\
\text { Asset-liability ration }(1 \%) \\
\text { Dividend capital ratio }(2 \%) \\
\text { Dividend yield (3\%) } \\
\text { Bonus share allocation ratio of profit }(3 \%) \\
\text { Number of penalties by stock exchange }(5 \%) \\
\text { R \& D expenditure }(1 \%) \\
\text { Concept of technological innovation }(1 \%) \\
\text { The number of items of technological innovation }(2 \%)\end{array}$ \\
\hline $\begin{array}{c}\text { Employees (weight ratio: } 15 \%, 10 \% \text { in consumption } \\
\text { sector) }\end{array}$ & $\begin{array}{c}\text { Performance }(5 \%) \\
\text { Safety }(5 \%) \\
\text { Caring for employees }(5 \%)\end{array}$ & $\begin{array}{c}\text { Per capita incomes of workers }(4 \%) \\
\text { Training of staff }(1 \%) \\
\text { Periodic security check }(2 \%) \\
\text { Safety training }(3 \%) \\
\text { Policy of caring }(1 \%) \\
\text { Number of caring }(2 \%) \\
\text { Caring payments }(2 \%)\end{array}$ \\
\hline $\begin{array}{c}\text { Customers and suppliers (weight ratio: } 15 \%, 10 \% \text { in } \\
\text { consumption sector) }\end{array}$ & $\begin{array}{l}\text { Product quality }(7 \%) \\
\text { Customer service }(3 \%) \\
\text { Mutual good faith }(5 \%)\end{array}$ & $\begin{array}{c}\text { Policy of quality management (3\%) } \\
\text { Quality management system certificate }(4 \%) \\
\text { Customer satisfaction survey }(3 \%) \\
\text { Vendor fair competition }(3 \%) \\
\text { Anti-bribery training }(2 \%)\end{array}$ \\
\hline $\begin{array}{l}\text { Environment (weight ratio: } 20 \%, 30 \% \text { in } \\
\text { manufacturing sector, } 10 \% \text { in service sector) }\end{array}$ & $\begin{array}{l}\text { Environmental governance } \\
\qquad(20 \%)\end{array}$ & $\begin{array}{c}\text { Policy of environmental protection }(2 \%) \\
\text { Environmental management system certificate }(3 \%) \\
\text { Environmental investment amount }(5 \%) \\
\text { Number of types of sewage }(5 \%) \\
\text { Number of types of green energy }(5 \%)\end{array}$ \\
\hline $\begin{array}{c}\text { Society (weight ratio: } 20 \%, 30 \% \text { in service sector, } 10 \% \\
\text { in manufacturing sector) }\end{array}$ & Contribution $(20 \%)$ & $\begin{array}{c}\operatorname{Tax}(10 \%) \\
\text { Donation amount }(10 \%)\end{array}$ \\
\hline
\end{tabular}

Specifically, the Hexun CSR rating adopts a weighted sum from the first-class five dimensions to the third-class indices in order to compose overall CSR score. The 38 third-class indices are assigned by Hexun rating staff members, where both mathematical computations and qualitative judgment are used. In terms of the numerical indicators, such as quick ratio in shareholder dimension and environmental investment amount in the environment dimension, the score is assigned based on Hexun's own data models. Regarding the qualitative indicators, such as the policy of quality management in customer and supplier dimension, the score is determined according to the rating staff's discretion about whether CSR reports disclose relevant items and include sufficient details. If no item is disclosed, then the score is 0 . As such, the score of third-class indices is normalized for obtaining second-class indices. These values are subsequently multiplied by the corresponding weight. The resulting sum provides the overall CSR score.

Prior literature contends that only the Hexun CSR rating provides an appropriate data source for assessing the CSR of Chinese listed companies [61]. Though RKS CSR rating is also another source frequently used in China [62]. However, according to a comparative study by Zhong et al. [63], Hexun criteria are more robust for measuring CSR performance than RKS which is primarily concerned with CSR reporting quality. In addition, Hexun CSR scoring is more objective because the evaluation is mainly based on the numerical calculation of specific indices, rather than content analysis like RKS CSR rating. Therefore, in the Chinese context, the Hexun rating system has been more commonly used in the performance evaluation of CSR activities of enterprises $[64,65]$. 
As per the Hexun criteria, the overall CSR score for a specific pharmaceutical firm may be calculated as the following equation:

CSR score $=30 \% \operatorname{CSR}(S H A)+30 \% \operatorname{CSR}(E M P)+15 \% \operatorname{CSR}($ CUST \& SUP $)+15 \% C S R(E N V)+10 \% \operatorname{CSR}(S O C)$,

where CSR(SHA), CSR(EMP), CSR(CUST \& SUP), CSR(ENV), and CSR(SOC) are corporate fulfillment towards the CSR dimensions of shareholders, employees, customers and suppliers, the environment, and society respectively. The score of each dimension, as well as the overall CSR score, were directly extracted from Hexun CSR rating.

\subsection{Firm Performance and Other Control Variables}

As measures of firm performance, Orlitzky et al. [28] proposed three aspects that are market-based, accounting-based, and perpetual-based. As McGuire et al. [66] point out, solely focusing on a single aspect may lead to individual bias. For example, market-based measures only consider market factors and they are vulnerably impacted by macroeconomic fluctuations [67], whilst accounting-based measures regard the historical perspective of an enterprise, subject to only past financial information [68]. To eliminate individual bias we included both market-based and accounting-based measures in this study. In this regard, we used Tobin's $Q$ as a proxy of market-based measure, and return on assets (ROA), return on equity (ROE), and earnings per share (EPS) as proxies of accounting-based measures. For a control variable, we used the natural logarithm of total assets to modulate the size of the sample. The details of variables measurements are shown in Table 3.

Table 3. Constructs of the variables.

\begin{tabular}{cl}
\hline Variables & \multicolumn{1}{c}{ Measurement } \\
\hline CSR-SHA & CSR performance on shareholders dimension was extracted from Hexun CSR database. \\
CSR-EMP & CSR performance on employees dimension was extracted from Hexun CSR database. \\
CSR-CUST \& SUP & CSR performance on customers and suppliers dimension was extracted from Hexun CSR database. \\
CSR-ENV & CSR performance on the environment dimension was extracted from Hexun CSR database. \\
CSR-SOC & CSR performance on society's dimension was extracted from Hexun CSR database. \\
CSR & The sum of score of five CSR dimensions extracted from Hexun CSR database \\
Tobin's Q & Tobin's Q = total market value of firm/total assets value of firm \\
ROA & Return on assets = net income/total average assets \\
ROE & Return on equity = net income/total average equity \\
EPS & Earnings per share = (net income - preferred dividends)/weighted average shares outstanding \\
LNTA & Natural logarithm of total assets \\
\hline
\end{tabular}

\section{Results and Discussions}

\subsection{Descriptive Statistics}

The descriptive statistics of all variables are shown in Table 4 . The mean and median value of CSR is 29.52 and 24.75 respectively, indicating that Chinese pharmaceuticals in our sample carry a relatively low CSR rating score, on a spectrum between 1 to 100. The standard deviation of CSR is 17.84, demonstrating that CSR performance appears quite differently across sample firms.

Meanwhile, the mean and median value of the shareholders' dimensions of stakeholders' responsibility (CSR-SHA) is 54.17 and 57.57, respectively, suggesting that sample companies attach great importance to shareholders' interests, compared to other dimensions. In particular, the negatively skewed distribution of CSR-SHA indicates that most of Chinese pharmaceuticals in our sample obtained lower than average score on shareholders' responsibility fulfillment. Comparing with CSR-SHA, society's dimension (CSR-SOC) and employees' dimension (CSR-EMP) of stakeholders' responsibility has lower mean values of 30.79 and 22.87, and median values of 28.35 and 12.30, respectively. Regarding customers' and suppliers' dimensions (CSR-CUST \& SUP) and the environmental aspect (CSR-ENV) of stakeholders' responsibility, the mean value is merely 14.56 and 10.40, respectively. 
It indicates that pharmaceutical firms have the lowest CSR score on environment as compared to other dimensions. Specifically, both CSR-CUST \& SUP, and CSR-ENV have zero median value, suggesting that on average, the sample firms fail to undertake due responsibility towards environmental protection, product safety, and suppliers' satisfaction.

Table 4. Descriptive statistics.

\begin{tabular}{cccccccc}
\hline Variables & No. of Observations & Median & Mean & Min. & Max. & S.D. & Skewness \\
\hline Tobin's Q & 875 & 2.689 & 3.242 & 0 & 16.854 & 2.232 & 1.798 \\
ROA & 875 & 0.660 & 0.069 & -0.298 & 0.494 & 0.641 & 0.204 \\
ROE & 875 & 0.095 & 0.106 & -0.911 & 6.918 & 0.256 & 21.848 \\
EPS & 875 & 0.417 & 0.550 & -1.148 & 4.100 & 0.593 & 1.960 \\
CSR & 875 & 24.7500 & 29.5180 & -11.4600 & 87.2200 & 17.8389 & 1.2651 \\
CSR-SHA & 875 & 57.567 & 54.174 & -11.433 & 92.333 & 20.466 & -0.749 \\
CSR-EMP & 875 & 12.300 & 22.874 & 0 & 100.000 & 26.016 & 1.582 \\
CSR-CUST \& SUP & 875 & 0 & 14.560 & 0 & 100.000 & 32.215 & 1.809 \\
CSR-ENV & 875 & 0 & 10.400 & 0 & 100.000 & 23.642 & 2.026 \\
CSR-SOC & 875 & 28.350 & 30.789 & -50.000 & 85.000 & 16.489 & -0.431 \\
LNTA & 875 & 21.669 & 21.716 & 19.032 & 25.0187 & 1.002 & 0.143 \\
\hline
\end{tabular}

Overall, our results indicate that although Chinese pharmaceutical firms have begun to realize their responsibility towards stakeholders and the environment, they are yet to achieve a satisfactory level of CSR performance. Moreover, shareholders are regarded as the most important stakeholders by Chinese pharmaceuticals to attain sustainability.

The correlation matrix for the dependent and independent variables is demonstrated in Table 5. The coefficients between all variables of firm performance are found to be significant at 0.01 level except Tobin's Q, indicating that the firms with higher accounting performance have better CSR performance than their counterparts. In addition, all CSR dimensions are positively correlated with accounting-based performance measures of ROA, ROE, and EPS. Though, Tobin's Q, the proxy of market-based performance, is not significantly associated with overall CSR indicator and individual stakeholders' dimensions except for shareholders dimension.

Table 5. Correlation analysis.

\begin{tabular}{|c|c|c|c|c|c|c|c|c|c|c|c|}
\hline & Tobin's Q & ROA & ROE & EPS & LNTA & CSR & CSR-SHA & CSR-EMP & $\begin{array}{l}\text { CSR-CUST } \\
\text { \& SUP }\end{array}$ & CSR-ENV & CSR-SOC \\
\hline Tobin's Q & 1 & & & & & & & & & & \\
\hline ROA & $0.350 * *$ & 1 & & & & & & & & & \\
\hline EPS & $0.072 *$ & 0.616 ** & 0.260 ** & 1 & & & & & & & \\
\hline LNTA & $0-.380 * *$ & $0.067 *$ & 0.015 & $0.326^{* *}$ & 1 & & & & & & \\
\hline CSR & -0.024 & $0.377^{* *}$ & $0.032 *$ & 0.424 ** & $0.294^{* *}$ & 1 & & & & & \\
\hline CSR-SHA & $0.155 * *$ & 0.693 ** & 0.222 ** & $0.590^{* *}$ & $0.272 * *$ & $0.610^{* *}$ & 1 & & & & \\
\hline CSR-ENV & -0.015 & 0.199 ** & $0.114^{* *}$ & $0.247^{* *}$ & $0.205^{* *}$ & 0.902 ** & $0.286^{* *}$ & $0.883^{* *}$ & 0.964 ** & 1 & \\
\hline CSR-SOC & $-0.080 *$ & $0.114 * *$ & $0.075^{*}$ & $0.097^{* *}$ & $0.135^{* *}$ & $0.499 * *$ & $0.157^{* *}$ & 0.298 ** & $0.332 * *$ & $0.335 * *$ & 1 \\
\hline
\end{tabular}

\subsection{Overall CSR and Firm Performance}

To examine the relationship between CSR and firm performance, we regress firm performance on the overall score of CSR and other control variables using the following regression model:

$$
\text { Firmperformance }_{i t}=\beta_{0}+\beta_{1} \operatorname{CSR}_{i t}+\beta_{2} L N T A_{i t}+\varepsilon_{i t},
$$

where, Firmperformance ${ }_{i t}$ is the performance of firm $i$ in year $t$, which is measured by accounting-based proxies of ROA, ROE, and EPS and market-based proxy such as Tobin's Q. CSR $R_{i t}$ is the CSR score of firm $i$ in year $t$. As discussed in Research Design, the CSR score is obtained from the Hexun CSR database. $L N T A_{i t}$ is the nature logarithm of total assets of firm $i$ in year $t$, and $\varepsilon_{i t}$ is the disturbance 
term. Based on Hypothesis 1, we expect the coefficient $\beta_{1}$ to be positive and statistically significant with firm performance.

Considering the structure of our data, a panel-based regression model is employed to control the unobserved heterogeneity in the proposed model. The Likelihood test is applied at first to examine whether fixed effects exist or not. Subsequently, Hausman test is used to choose between fixed-effects and random-effects. The outcome suggests that fixed-effects is the appropriate specification in examining the relationship between CSR with Tobin's Q, and CSR with ROA and EPS. The random-effects model is employed in examining the relationship between CSR with ROE based on the outcome of the Likelihood test.

Regression results are demonstrated in Table 6. CSR has a significant coefficient with $(p<0.05)$ ROA, ROE, and EPS. These results indicate that an increase in CSR score enables firms to enhance their accounting performances. However, the model depicts that the coefficient between CSR and Tobin's $Q$ is significantly negative. Suggesting that in China's context, positive CSR practices hardly help pharmaceuticals improve market performance. On the whole, the results of above models are consistent with our first hypothesis which claims that engagement in CSR activities increases firm performance. These findings are in line with the previous research investigating CSR and firm performance in China [69].

Table 6. Panel-based regression models: CSR as the independent variable.

\begin{tabular}{ccccc}
\hline \multicolumn{5}{c}{ Dependent Variables } \\
\hline & Tobin's Q & ROA & ROE & EPS \\
\hline Independent & & & \\
variable & & & \\
CSR & $-0.0345^{* * *}$ & $0.0009^{* * *}$ & $0.0033^{*}$ & $0.0059^{* * *}$ \\
Control variable & & & & \\
Size & $-2.2433^{* * *}$ & -0.0071 & $-0.1025^{* * *}$ & $0.1051^{* *}$ \\
Constant & $51.1818^{* * *}$ & 0.1981 & $2.2582^{* * *}$ & $-1.9091^{*}$ \\
Adjusted R2 & $0.6523^{* * *}$ & 0.5296 & 0.3973 & $0.6707^{* *}$ \\
F-statistics & $12.8926^{* *}$ & $8.3383^{* * *}$ & $7.0462^{* * *}$ & $14.2751^{* * *}$ \\
Durbin-Watson & 2.2095 & 1.8129 & 2.3988 & 1.1661 \\
\hline & Notes: ${ }^{*} p<0.05^{* *} p<0.01,{ }^{* * *} p<0.001$. &
\end{tabular}

The instrumental aspect of stakeholder theory enables to explain the positive association between CSR and firm performance. The theory attempts to investigate the benefit of CSR activities by incorporating the demands of stakeholders and social trustworthiness. Engaging in CSR related endeavors assist Chinese pharmaceuticals to maintain sound relationships with key stakeholders, who can create, develop, and maintain link to strategic resources [50]. Particularly, some resources are difficult to acquire or duplicate by the rivals that can be counted as a competitive advantage of a firm. Accordingly, firm performance can be enhanced through active externalities with stakeholders accessed by the CSR practices.

\subsection{Impact of Individual CSR Dimensions on Firm Performance}

To further investigate the effects of a particular CSR dimension of stakeholders on firm performance, we regress firm performance with shareholders dimension, employees dimension, customers and suppliers dimension, the environment dimension and society's dimension, respectively. The model specification is presented below:

$$
\text { Firmperformance }_{i t}=\beta_{0}+\beta_{1} \text { StakeholdersDimension }_{i t}+\beta_{2} L N T A_{i t}+\varepsilon_{i t}
$$

where, StakeholdersDimension ${ }_{\mathrm{it}}$ is performance of stakeholders' practices of firm $i$ in year $t$, which are denoted as CSR-SHA, CSR-EMP, CSR-CUST \& SUP, CSR-ENV, and CSR-SOC, respectively. As proposed 
in Hypothesis 2, we expect the relationship between each dimension of stakeholders and firm performance to be positive and statistically significant.

We regress accounting performance proxies with each individual dimension in a panel-based regression setting. The results of the Hausman test imply that the dimensions of shareholders (CSR-SHA), employees (CSR-EMP), customers and suppliers (CUST \& SUP), and the environment (CSR-ENV) are appropriate in a fixed-effects model when examining the relationship with Tobin's $Q$, ROA, and EPS. However, the random-effects model is appropriate to observe the relationship with ROE. Likewise, for the society dimension of CSR, a random-effects model is used in examining the relationship with Tobin's $Q$. The fixed-effects specification is adopted to examine the association with ROA and EPS, whereas the pooled model is developed to test the association with ROE.

The results of the panel-based models concerning different CSR dimensions of stakeholders are shown in Table 7. Specifically, the shareholders dimension has a positive significant $(p<0.05)$ coefficient with Tobin's Q, ROA, ROE, and EPS. These results depict that the efforts to promote shareholders' welfare yield higher market-based and accounting-based performance for Chinese pharmaceuticals. Hence, CSR practices help firms to promote shareholder trust and attract new investors who are sensitive toward companies' CSR activities, thus leading to better financial performance. These findings are consistent with the previous research $[47,54]$.

Table 7. Panel-based regression models: CSR dimensions as the independent variables.

\begin{tabular}{ccccc}
\hline & \multicolumn{3}{c}{ Dependent Variables } \\
\hline & Tobin's Q & ROA & ROE & EPS \\
\hline Independent Variable & & & & \\
Shareholders (CSR-SHA) & $0.0038^{* *}$ & $0.0016^{* * *}$ & $0.0026^{* * *}$ & $0.0105^{* * *}$ \\
Employees (CSR-EMP) & -0.0017 & $0.0001^{* * *}$ & $0.0012^{* * *}$ & $0.0005^{*}$ \\
Customers and suppliers (CSR-CUST \& SUP) & -0.0014 & $0.0001^{* *}$ & $0.0008^{* * *}$ & 0.0001 \\
The environment (CSR-ENV) & -0.0016 & $0.0001^{* *}$ & $0.0009^{* * *}$ & 0.0002 \\
Society (CSR-SOC) & -0.0023 & $0.0001^{* *}$ & $0.0004^{* * *}$ & 0.0010 \\
\hline
\end{tabular}

Notes: ${ }^{*} p<0.05,{ }^{* *} p<0.01,{ }^{* * *} p<0.001$.

Table 7 also illustrates that a positive significant $(p<0.05)$ relationship exists between the employees dimension of CSR and the firm's accounting performance measures. Given that the Labor Contract Law was enacted nation-wide [70], the protection of employees' rights has witnessed a considerable improvement in China. Promoting sound labor practices assist companies to attract, retain, and motivate employees. Turnover rate may also decrease, hence leading to an increase in productivity [53]. Overall, our results confirm that CSR efforts to promote labor protection help Chinese pharmaceuticals to improve financial performance.

Similarly, the customers and suppliers dimension of CSR has a significant $(p<0.05)$ and positive association with ROA and ROE. This empirical outcome is in line with [54] and [52], which emphasizes that providing high-quality products and services enables firms to differentiate themselves from competitors and build strong customer loyalty. Likewise, establishing trust and fairness with suppliers help firms to reduce the cost of defective goods during the procurement process. Therefore, promoting better CSR practices with customers and suppliers is positively associated with firm performance.

The environment aspect of CSR has received enormous attention from the public and the Chinese government in recent years and the results are shown in Table 7 and indicates that the environmental dimension of the firm's CSR activities significantly $(p<0.05)$ and positively link with both ROA and ROE. The promising CSR activities regarding environmental preservation and protection enable companies to receive approval of the relevant regulatory authorities. Therefore, such firms benefit from lower operating costs incurred through insurance and fines concerning environmental degradation [55]. The environment-related CSR efforts assist companies to act as responsible corporate citizens and attract more attention form environment-sensitive investors. 
The last dimension of CSR practices towards society is found to be significantly $(p<0.05)$ and positively associated with ROA and ROE. These results assert that actively contributing to social activities, such as community development and charitable donations creates an overall positive image of an enterprise. Moreover, it enables firms to lobby for tax concessions and other financial benefits $[47,71]$. Besides, promoting corporate citizenship through proactive social activities help firms to negotiate for favorable policies with the government to attain reasonable profitability.

Overall, the above regression models positively relate CSR dimensions with enterprise performance, thus support the hypothesis of this study which proposes that a particular aspect of CSR positively contributes to a firm's financial performance. These findings corroborate with the instrumental aspect of stakeholder theory which proposes that a firm can benefit from CSR activities by effectively responding to its stakeholders' demands. Efficient stakeholder management enables Chinese pharmaceuticals to mitigate adverse effects on society. Specifically, sound labor relations can lower hiring costs and ameliorate productivity [53]. Likewise, a favorable social image helps to gain positive goodwill that can buffer a pharmaceutical from unanticipated problems. Moreover, such practices can pave the way for valuable opportunities that are not available to poor CSR firms [4]. Therefore, actively responding to various groups of stakeholders can bring out competitive advantages to an enterprise, consequently resulting in superior economic returns.

\section{Conclusions}

This study was set out to investigate whether CSR efforts enhance firm performance in the context of pharmaceutical companies in China. Based on the stakeholder theory and the CSR stakeholder framework outlined by the Hexun CSR database, we develop five CSR dimensions to measure various aspects of CSR performance, and incorporate them to measure the overall CSR score. By examining CSR practices between 2010 and 2016 among 125 Chinese pharmaceutical companies we conclude that CSR helps to improve firm's financial performance. Moreover, all of the five CSR dimensions identified in the study relates positively to firm performance. However, the results suggest that the environment is regarded as the most critical CSR dimension to optimize firm performance. This outcome is attributed to the stringent environmental regulations promulgated by the Chinese government in recent years. Whereas, the score on society dimension slightly lags behind other dimensions of CSR.

As a matter of fact, many Chinese firms hesitate to actively participate in CSR activities as they dread that such practices may not promote firm profitability or performance in the stock market. However, the empirical outcomes of this study suggest that CSR endeavors can yield sustainable firm performance. Specifically, CSR activities assist companies to maintain good relations with key stakeholders by creating a favorable perception of their operations. Hence such firms can establish a strong brand image and customer loyalty which can serve as a competitive advantage. Consequently, revenue and market share leads to better financial performance.

The extant literature predominantly focused on the CSR practices of advanced countries. Nevertheless, emerging economies have an underdeveloped CSR framework which makes it interesting to see how CSR activities impact firm performance in emerging markets like China. Furthermore, in the backdrop of numerous health- and environment-related incidents reported in Chinese pharmaceutical companies in recent years we chose the pharmaceutical industry as our research sample. Thus extending the previous research on CSR which does not specialize in a particular sector. In addition, unlike previous studies, which take the overall CSR score to assess a firm's CSR performance, we empirically tested the impact of each individual dimension of CSR on the financial performance of Chinese pharmaceuticals. Hence, we provide more extensive insight into the multifaceted CSR endeavors.

Our findings have several practical implications. First, given the poor CSR performance and practices regarding the environment dimension, Chinese pharmaceutical firms need to step up efforts to promote environment-related socially responsible activities. Second, the positive association between CSR and firm performance should also motivate companies to realize promising financial gains through CSR enforcement. Hence, CSR practices should be embedded within the firm's planning, controlling, 
and decision-making process. Third, Chinese regulators need to implement rigorous CSR regulations. For instance, the government can impose heavy fines in case of CSR violations. The monetary incentives such as tax breaks and the granting of subsidies to firms with exceptional CSR performance can also be introduced to achieve this goal.

Though, the study is not without limitations. First, we did not account for the impact of the business cycle on the proposed relationship between CSR indicators and firm performance. Second, the effect of time lag can be employed in the analysis to see how a change in a firm's performance reflects in later years with a corresponding change in CSR practices. Further studies can incorporate such factors to extend this line of research.

Author Contributions: M.Y., P.B., and A.A. carried out the conceptualization, research design, data collection, data analysis, write up, and review of this research project. All authors approved the final manuscript.

Funding: This research was funded by the Department of Education of Guangdong Province, China under grant number 2017WQNCX194.

Acknowledgments: The authors acknowledge administrative support from International Business School, Guangzhou College of South China University of Technology, and scientific support by ISCTE Business School, University Institute of Lisbon.

Conflicts of Interest: The authors declare no conflict of interest.

\section{Appendix A}

Table A1. Sample pharmaceutical companies.

\begin{tabular}{|c|c|c|c|c|c|}
\hline $\mathbf{S} / \mathbf{N}$ & Code & Name of the Company & $\mathrm{S} / \mathrm{N}$ & Code & Name of the Company \\
\hline 1 & 000004 & CAU Technology & 64 & 300049 & Fu-rui Pharmaceutical \\
\hline 2 & 000078 & Neptunus Group & 65 & 300110 & Huaren Pharmaceutical \\
\hline 3 & 000153 & BBCA Pharmaceutical & 66 & 300119 & Ruipu Biological \\
\hline 4 & 000403 & Shenghua Pharmaceutical & 67 & 300122 & Zhifei Biological \\
\hline 5 & 000423 & Dongeejiao Group & 68 & 300138 & CCGB Biological \\
\hline 6 & 000513 & Livzon Pharmaceutical & 69 & 300142 & Walvax Biotechnology \\
\hline 7 & 000518 & Sihuan Biological & 70 & 300158 & Zhengdong Group \\
\hline 8 & 000538 & Yunnai baiyao & 71 & 300181 & Zuoli Pharmaceutical \\
\hline 9 & 000545 & Jinpu Group & 72 & 300194 & Fuan Pharmaceutical \\
\hline 10 & 000590 & Guhan Group & 73 & 300199 & Hanyu Biological \\
\hline 11 & 000597 & Northeast Pharmaceutical & 74 & 300204 & Staidson Bio-pharmaceutical \\
\hline 12 & 000606 & Shenzhou Yiqiao & 75 & 300239 & Dongbao Biological \\
\hline 13 & 000623 & Jilin Aodong Medical & 76 & 300254 & CY Pharmaceutical \\
\hline 14 & 000650 & Renhe Pharmaceutical & 77 & 300255 & CSBIO Group \\
\hline 15 & 000661 & Changchun Gaoxin & 78 & 300267 & Erkang Pharmaceutical \\
\hline 16 & 000739 & Apeloa Pharmaceutical & 79 & 300289 & Leadman Biological \\
\hline 17 & 000756 & Xinhua Pharmaceutical & 80 & 300294 & Boya Pharmaceutical \\
\hline 18 & 000766 & Tonghua Jinma & 81 & 600062 & DCPC Pharmaceutical \\
\hline 19 & 000788 & PKU Health care & 82 & 600079 & HumanWell Healthcare \\
\hline 20 & 000915 & Sd-Wit Group & 83 & 600129 & Taiji Group \\
\hline 21 & 000919 & Jinlin Pharmaceutical & 84 & 600161 & Tiantan Biological \\
\hline 22 & 000952 & Guangji Pharmaceutical & 85 & 600195 & CAHIC Group \\
\hline 23 & 000989 & JZT Pharmaceutical & 86 & 600196 & Fosun Pharmaceutical \\
\hline 24 & 000990 & Chengzhi Group & 87 & 600201 & Jinyu Bio-technology \\
\hline 25 & 000999 & 999 Pharmaceutical & 88 & 600211 & Tibet Pharmaceutical \\
\hline 26 & 002001 & NHU group & 89 & 600222 & Tailong Pharmaceutical \\
\hline 27 & 002004 & Huapont Life Science & 90 & 600252 & Zhongheng Group \\
\hline 28 & 002007 & Hualan Biological & 91 & 600267 & Hisun Pharmaceutical \\
\hline 29 & 002020 & Jinxin Pharmaceutical & 92 & 600276 & Hengrui Medicine \\
\hline 30 & 002022 & Kehua Biological & 93 & 600285 & Lingrui Pharmaceutical \\
\hline 31 & 002030 & Daan Gene & 94 & 600329 & Zhongxin Pharmaceutical \\
\hline 32 & 002038 & Shuanglu Pharmaceutical & 95 & 600332 & BYS Pharmaceutical \\
\hline 33 & 002099 & Hisoar Pharmaceutical & 96 & 600351 & Yabao Pharmaceutical \\
\hline 34 & 002107 & Wohua Pharmaceutical & 97 & 600380 & Joincare \\
\hline
\end{tabular}


Table A1. Cont.

\begin{tabular}{cccccc}
\hline S/N & Code & Name of the Company & S/N & Code & Name of the Company \\
\hline 35 & 002118 & Zixin Pharmaceutical & 98 & 600420 & Shyndec Pharmaceutical \\
36 & 002166 & Layn Biological & 99 & 600422 & KPC Pharmaceutical \\
37 & 002198 & Jiaying Pharmaceutical & 100 & 600436 & Pien Tze Huang \\
38 & 002219 & Hengkang Medical & 101 & 600466 & BRC Group \\
39 & 002252 & Shanghai RAAS & 102 & 600479 & Qianjin Pharmaceutical \\
40 & 002275 & Sanjin Pharmaceutical & 103 & 600488 & Tianyao Pharmaceutical \\
41 & 002287 & Cheezheng Pharmaceutical & 104 & 600513 & Lianghuang Group \\
42 & 002294 & Salubris Pharmaceutical & 105 & 600518 & Kangmei Pharmaceutical \\
43 & 002317 & ZS Pharmaceutical & 106 & 600521 & Huahai Pharmaceutical \\
44 & 002332 & Xianju Pharmaceutical & 107 & 600530 & Onlly Group \\
45 & 002349 & Jinghua Pharmaceutical & 108 & 600535 & Tasly Group \\
46 & 002370 & Yatai Pharmaceutical & 109 & 600557 & Kanion Pharmaceutical \\
47 & 002393 & Lisheng Pharmaceutical & 110 & 600572 & Conba Group \\
48 & 002399 & Hepalink Pharmaceutical & 111 & 600594 & Yibai Pharmaceutical \\
49 & 002412 & Hansen Pharmaceutical & 112 & 600613 & Shengqi Pharmaceutical \\
50 & 002422 & Kelun Pharmaceutical & 113 & 600664 & Hayao Pharmaceutical \\
51 & 002424 & Bailing Pharmaceutical & 114 & 600671 & HZTM Pharmaceutical \\
52 & 002433 & Pibao Pharmaceutical & 115 & 600750 & Jiangzhong Pharmaceutical \\
53 & 002437 & Gloria Pharmaceutical & 116 & 600771 & Guangyuyuan \\
54 & 002550 & Qianhong Bio-pharma & 117 & 600781 & Furen Pharmaceutical \\
55 & 002566 & Yisheng Pharmaceutical & 118 & 600789 & Lukang Pharmaceutical \\
56 & 002603 & Yiling Pharmaceutical & 119 & 600803 & ENN Group \\
57 & 002644 & Foci Pharmaceutical & 120 & 600812 & Huabei Pharmaceutical \\
58 & 002653 & Haisco Pharmaceutical & 121 & 600829 & RMTT Pharmaceutical \\
59 & 300006 & Laimei Pharmaceutical & 122 & 600867 & Dongbao Pharmaceutical \\
60 & 300009 & Anke Biological & 123 & 600869 & Zhihui Group \\
61 & 300016 & Beilu Pharmaceutical & 124 & 600976 & Jianmin Group \\
62 & 300026 & Chasesun Pharmaceutical & 125 & 600993 & Mayinglong \\
63 & 300039 & Kaibao Pharmaceutical & & & \\
\hline & & & & &
\end{tabular}

\section{References}

1. Amran, A.; Fauzi, H.; Purwanto, Y.; Darus, F.; Yusoff, H.; Zain, M.M.; Naim, D.M.A.; Nejati, M. Social responsibility disclosure in Islamic banks: A comparative study of Indonesia and Malaysia. J. Financ. Rep. Account. 2017, 15, 99-115. [CrossRef]

2. Hackston, D.; Milne, M.J. Some determinants of social and environmental disclosures in New Zealand companies. Account. Audit. Account. J. 1996, 9, 77-108. [CrossRef]

3. Lin, L.W. Corporate social responsibility in China: Window dressing or structural change. Berkeley J. Int. Law 2010, 28, 64-100.

4. Zhu, Q.; Liu, J.; Lai, K. Corporate social responsibility practices and performance improvement among Chinese national state-owned enterprises. Int. J. Prod. Econ. 2016, 171, 417-426. [CrossRef]

5. Margolis, J.D.; Walsh, J.P. Misery loves companies: Rethinking social initiatives by business. Adm. Sci. Q. 2003, 48, 268-305. [CrossRef]

6. Brammer, S.; Millington, A. Does it pay to be different? An analysis of the relationship between corporate social and financial performance. Strateg. Manag. J. 2008, 29, 1325-1343. [CrossRef]

7. Hillman, A.; Keim, G. Shareholder value, stakeholder management, and social issues: What's the bottom line? Strateg. Manag. J. 2001, 22, 125-139. [CrossRef]

8. Campbell, J.L. Why would corporations behave in socially responsible ways? an institutional theory of corporate social responsibility. Acad. Manag. Rev. 2007, 32, 946-967. [CrossRef]

9. Surroca, J.; Tribo, J.A.; Waddock, S. Corporate responsibility and financial performance: The role of intangible resources. Strateg. Manag. J. 2010, 31, 463-490. [CrossRef]

10. Ann, T.N.; Wayne, O.; Rob, H. Capabilities, proactive CSR and financial performance in SMEs: Empirical evidence from Australian manufacturing industry sector. J. Bus. Ethics 2012, 109, 483-500. 
11. Ducassy, I. Does corporate social responsibility pay off in times of crisis? An alternate perspective on the relationship between financial and corporate social performance. Corp. Soc. Responsib. Environ. Manag. 2013, 20, 157-167. [CrossRef]

12. Tang, L.; Gallagher, C.C.; Bie, B. Corporate social responsibility communication through corporate websites: A comparison of leading corporations in the United States and China. Int. J. Bus. Commum. 2015, 52, $205-227$. [CrossRef]

13. Zhang, W.; Xue, J. Economically motivated food fraud and adulteration in China: An analysis based on 1553 media reports. Food Control 2016, 67, 192-198. [CrossRef]

14. Smith, A.D. Corporate social responsibility practices in the pharmaceutical industry. Bus. Strateg. Ser. 2008, 9, 306-315. [CrossRef]

15. Esteban, D. Strengthening corporate social responsibility in the pharmaceutical industry. J. Med. Mark. 2008, 8,77-79. [CrossRef]

16. Lin, X.F.; Xiao, D.D.; Liu, W.J.; Liu, C.J. The analysis and model reconstruction of corporate social responsibility in Chinese pharmaceutical companies. Med. Soc. 2011, 24, 368-371. (In Chinese)

17. Wang, X.Q.; Xu, P. The empirical study on CSR for Pharmaceutical firms based on stakeholder theory. Stud. Ind. Econ. 2011, 7, 97-98. (In Chinese)

18. China Food and Drug Administration. The News of Drug-Related Product Accidents. Available online: http://samr.cfda.gov.cn/WS01/CL0412/ (accessed on 30 March 2019).

19. Bichta, C. Corporate socially responsible (CSR) practices in the context of Greek industry. Corp. Soc. Responsib. Environ. Manag. 2003, 10, 12-24. [CrossRef]

20. Frederick, W.C. The growing concern over social responsibility. Calif. Manag. Rev. 1960, 2, 54-61. [CrossRef]

21. Davis, K. Can business afford to ignore social responsibility. Calif. Manag. Rev. 1960, 2, 70-76. [CrossRef]

22. Johnson, H.L. A berkeley view of business and society. Calif. Manag. Rev. 1973, 16, 95-100. [CrossRef]

23. Committee for Economic Development. Social Responsibility of Business Corporations; Research and Business Policy Committee: New York, NY, USA, 1971.

24. Carroll, A.B. The pyramid of corporate social responsibility: Toward the moral management of organizational stakeholders. Bus. Horiz. 1991, 34, 39-48. [CrossRef]

25. Freeman, R.E. Strategic Management: A Stakeholder Approach; Pittman: Boston, MA, USA, 1984.

26. Matten, D.; Crane, A.; Chapple, W. Behind the mask: Revealing the true face of corporate citizenship. J. Bus. Ethics 2003, 45, 109-120. [CrossRef]

27. Doane, D. The myth of CSR: The problem with assuming that companies can do well while also doing good is that markets don't really work that way. Stanf. Soc. Innov. Rev. 2005, 3, 22-29.

28. Orlitzky, M.; Rynes, S.L.; Schmidt, F.L. Corporate social and financial performance: A meta-analysis. Organ. Stud. 2003, 24, 403-441. [CrossRef]

29. McWilliams, A.; Siegel, D.S. Corporate social responsibility: A theory of the firm perspective. Acad. Manag. Rev. 2001, 26, 117-127. [CrossRef]

30. Porter, M.E.; Kramer, M.R. The link between competitive advantage and corporate social responsibility. Harv. Bus. Rev. 2006, 84, 78-92.

31. Mohr, L.A.; Webb, D.J.; Harris, K.E. Do Consumers expect companies to be socially responsible? The impact of corporate social responsibility on buying behavior. J. Consum. Aff. 2001, 35, 45-72. [CrossRef]

32. Jamali, D. The case for strategic corporate social responsibility in developing countries. Bus. Soc. Rev. 2007, 112, 1-27. [CrossRef]

33. Crane, A.; Matten, D. Business Ethics: Managing Corporate Citizenship and Sustainability in the Age of Globalization; Oxford University Press: Oxford, UK, 2007.

34. Griesse, M.A. The geographic, political, and economic context for corporate social responsibility in Brazil. J. Bus. Ethics 2007, 73, 21-37. [CrossRef]

35. Alkhatib, J.A.; Rawwas, M.Y.; Vitell, S.J. Organizational ethics in developing countries: A comparative analysis. J. Bus. Ethics 2004, 55, 309-322.

36. Chen, H.; Wang, X. Corporate social responsibility and corporate financial performance in China: An empirical research from Chinese firms. Corp. Gov. 2011, 11, 361-370. [CrossRef]

37. Visser, W. Corporate Citizenship in a Development Perspective; Copenhagen Business School Press: Copenhagen, Denmark, 2006.

38. Ministry of Commerce of China. Chinese Company Law; Ministry of Commerce of China: Beijing, China, 1994. 
39. Ministry of Commerce of China. Chinese Company Law; Ministry of Commerce of China: Beijing, China, 2006.

40. State-Owned Assets Supervision and Administration Commission of the State Council (SASAC). Guidance for Social Responsibility Implementation for the Stated-Owned Enterprise; SASAC: Beijing, China, 2008.

41. State-Owned Assets Supervision and Administration Commission of the State Council. Guide on the SOEs' Better Performance of CSR; SASAC: Beijing, China, 2016.

42. Shanghai Stock Exchange (SHSE). Guide on Environmental Information Disclosure; SHSE: Shanghai, China, 2018.

43. Maignan, I.; Ferrell, O.C.; Hult, G.T.M. Corporate citizenship in two countries: The case of the United States and France. J. Bus. Ethics 2000, 23, 283-297. [CrossRef]

44. Crilly, D.; Zollo, M.; Hansen, M.T. Faking it or muddling through? Understanding decoupling in response to stakeholder pressures. Acad. Manag. J. 2012, 55, 1429-1448. [CrossRef]

45. Donaldson, T.; Preston, L.E. The stakeholder theory of the corporation: Concepts, evidence and implications. Acad. Manag. Rev. 1995, 20, 65-91. [CrossRef]

46. Jones, T.M. Instrumental stakeholder theory: A synthesis of ethics and economics. Acad. Manag. Rev. 1995, 20, 404-437. [CrossRef]

47. Barnett, M.L.; Salomon, R.M. Beyond dichotomy: The curvilinear relationship between social responsibility and financial performance. Strateg. Manag. J. 2006, 27, 1101-1122. [CrossRef]

48. Hou, T.C.T. The relationship between corporate social responsibility and sustainable financial performance: Firm-level evidence from Taiwan. Corp. Soc. Responsib. Environ. Manag. 2019, 26, 19-28. [CrossRef]

49. Lu, R.X.A.; Lee, P.K.C.; Cheng, T.C.E. Socially responsible supplier development: Construct development and measurement validation. Int. J. Prod. Econ. 2012, 140, 160-167. [CrossRef]

50. Wood, D.J.; Jones, R.E. Stakeholder mismatching: A theoretical problem in empirical research on corporate social performance. Int. J. Organ. Anal. 1995, 3, 229-267. [CrossRef]

51. Weiss, J.W. Business Ethics: A Stakeholder and Issues Management Approach; South-Western College Publications: Cincinnati, OH, USA, 2008.

52. Pan, X.; Sha, J.; Zhang, H.; Ke, W. Relationship between Corporate Social Responsibility and Financial Performance in the Mineral Industry: Evidence from Chinese Mineral Firms. Sustainability 2014, 6, 4077-4101. [CrossRef]

53. Turban, D.B.; Greening, D.W. Corporate social performance and organizational attractiveness to prospective employees. Acad. Manag. J. 1997, 40, 658-672.

54. Branco, M.C.; Rodrigues, L.L. Corporate social responsibility and resource-based perspective. J. Bus. Ethics 2006, 69, 111-132. [CrossRef]

55. Hart, S.L.; Ahuja, G. Does it pay to be green? An empirical examination of the relationship between emission reduction and firm performance. Bus. Strateg. Environ. 1996, 5, 30-37. [CrossRef]

56. Wu, W.; Liu, Y.; Chin, T.; Zhu, W. Will green CSR enhance innovation? A perspective of public visibility and firm transparency. Int. J. Environ. Res. Public Health 2018, 15, 268. [CrossRef] [PubMed]

57. Jiang, X.; Akbar, A. Does increased representation of female executives improve corporate environmental investment? Evidence from China. Sustainability 2018, 10, 4750. [CrossRef]

58. Waddock, S.A.; Graves, S.B. Quality of management and quality of stakeholder relations: Are they synonymous? Bus. Soc. 1997, 36, 250-279. [CrossRef]

59. Ma, A.Y.; Jiang, Z.H.; Li, W. The relationship between CSR and financial performance: An empirical study for food and drinking companies. Commun. Financ. Account. 2015, 33, 109-111. (In Chinese)

60. Hexun CSR Evaluation System. Available online: http://stock.hexun.com/2013/gsshzr/index.html (accessed on 19 January 2019).

61. Xiong, B.; Lu, W.; Skitmore, M.; Chau, K.W.; Ye, M. Virtuous nexus between corporate social performance and financial performance: A study of construction enterprises in China. J. Clean. Prod. 2016, 129, 223-233. [CrossRef]

62. Lee, E.; Walker, M.; Zeng, C.C. Do Chinese state subsidies affect voluntary corporate social responsibility disclosure? J. Account. Public Policy 2017, 36, 179-200. [CrossRef]

63. Zhong, M.; Xu, R.; Liao, X.; Zhang, S. Do CSR ratings converge in China? A comparison between RKS and Hexun scores. Sustainability 2019, 11, 3921. [CrossRef]

64. Tang, P.; Yang, S.; Boehe, D. Ownership and corporate social performance in China: Why geographic remoteness matters. J. Clean. Prod. 2018, 197, 1284-1295. [CrossRef] 
65. Zheng, G.; Wang, S.; Xu, Y. Monetary stimulation, bank relationship and innovation: Evidence from China. J. Bank. Financ. 2018, 89, 237-248. [CrossRef]

66. McGuire, J.B.; Sundgren, A.; Schneeweis, T. Corporate social responsibility and firm financial performance. Acad. Manag. J. 1988, 31, 854-872.

67. Ullmann, A. Data in search of a theory: A critical examination of the relationships among social performance, social disclosure, and economic performance. Acad. Manag. Rev. 1985, 10, 540-577.

68. Branch, B. Misleading Accounting: The Danger and the Potential; Working paper; University of Massachusetts: Amherst, MA, USA, 1983.

69. Sial, M.; Zheng, C.; Cherian, J.; Gulzar, M.; Thu, P.; Khan, T.; Nguyen, V. Does corporate social responsibility mediate the relation between boardroom gender diversity and firm performance of Chinese listed companies? Sustainability 2018, 10, 3591. [CrossRef]

70. The State Council of China, Labor Contract Law of China. Available online: http://www.gov.cn/flfg/2008-09/ 19/content_1099500.htm (accessed on 19 September 2008).

71. Laan, G.V.D.; Ees, H.V.; Witteloostuijn, A.V. Corporate social and financial performance: An extended stakeholder theory, and empirical test with accounting measures. J. Bus. Ethics 2008, 79, 299-310. [CrossRef]

(C) 2019 by the authors. Licensee MDPI, Basel, Switzerland. This article is an open access article distributed under the terms and conditions of the Creative Commons Attribution (CC BY) license (http://creativecommons.org/licenses/by/4.0/). 